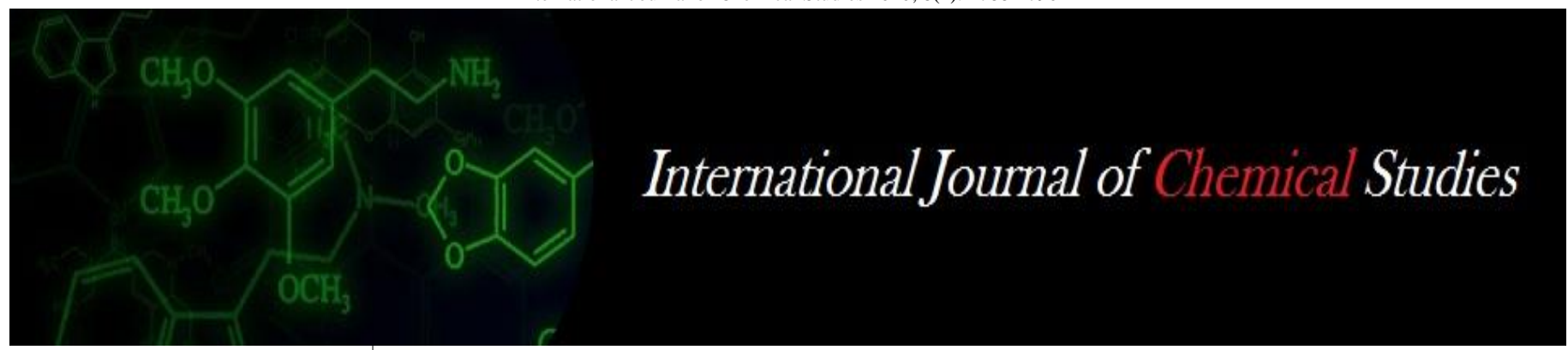

P-ISSN: 2349-8528

E-ISSN: 2321-4902

IJCS 2020; 8(1): 1788-1790

(C) 2020 IJCS

Received: 22-11-2019

Accepted: 24-12-2019

Jaydip B Anarse

P.G. Student, Department of

Plant Pathology, Vasantrao

Naik Marathwada Krishi

Vidyapeeth, Parbhani,

Maharashtra, India

\section{KT Apet}

Professor and Head, Department

of Plant Pathology, Vasantrao

Naik Marathwada Krishi

Vidyapeeth, Parbhani,

Maharashtra, India

Ashwini V Kubde

Ph.D. Scholar, Department of

Plant Pathology and Agril.

Microbiology, Mahatma Phule

Krishi Vidyapeeth, Rahuri,

Maharashtra, India

\section{Sindhu T Surner}

Ph.D. Scholar, Department of

Plant Pathology and Agril.

Microbiology, Mahatma Phule

Krishi Vidyapeeth, Rahuri,

Maharashtra, India

\section{Effect of various culture media on growth of Pleurotus eous}

\author{
Jaydip B Anarse, KT Apet, Ashwini V Kubde and Sindhu T Surner
}

DOI: https://doi.org/10.22271/chemi.2020.v8.i1z.8525

\begin{abstract}
A preliminary experiment was carried out to analyse the growth performance of $P$. eous mushroom cultures using different media. Eight culture media viz., Ashby's manitol agar, yeast extract agar, yeast manitol agar, Corn meal agar, Potato dextrose agar, potato malt agar, Czapek's dox agar and Malt extract agar were used. The maximum colony diameter of $P$. eous was recorded on potato dextrose agar (90 $\mathrm{mm})$, followed by Malt extract agar $(88.16)$, Yeast manitol agar $(87.50 \mathrm{~mm})$, Yeast extract agar $(86.33$ $\mathrm{mm}$ ), Corn meal agar (86.10), Potato malt extract (85.66) and minimum colony diameter was recorded on Ashby's manitol agar $(14.66 \mathrm{~mm})$ which was lesser than Czapek's dox agar $(85.30 \mathrm{~mm})$.
\end{abstract}

Keywords: Pleurotus eous, culture media, potato dextrose agar, corn meal agar

\section{Introduction}

Mushrooms were so far considered as luxury food especially among the rich community because of their unique flavor and excitingly different taste but now they have grown to a common mans food. Mushrooms are traced as special kind of food, since ancient times. The Greeks believed that mushrooms provided strength for warriors in battle and Romans regarded them as "Food of Gods" or "Gods Flesh", which were served only on festival occasions.

China leads in world mushroom production by cultivating more than 20 different types of mushrooms on commercial scale. USA is the second largest producer of mushrooms sharing 16 per cent of the world production (Prakasam, 2012; Singh et al., 2011) ${ }^{[8,10]}$. Currently India stands 54 in the world ranking of mushroom producers. India ranks $6^{\text {th }}$ and world market share 4.44 per cent. Mushroom production in India has been estimated at 48000 tonnes per annum. At present, only three mushrooms viz., button mushroom (Agaricus bisporus), oyster mushroom (Pleurotus spp.) and paddy straw mushroom (Volvariella spp.) is being cultivated on commercial and small scale in India. Button mushroom is mainly cultivated in mechanized mushroom farms on commercial scale in States such as Jammu \& Kashmir, Himachal Pradesh, Uttaranchal, etc. To date approximately 70 species of oyster mushroom (Pleurotus spp.) have been recorded. The oyster mushroom (Pleurotus spp.) also called 'Dhingri or Abalone' (Chadha and Sharma, 1995) ${ }^{[2]}$. Oyster mushroom is usually coloured including dark blue, white, cream, brown, or yellow and pink.

Oyster (Pleurotus spp.) mushroom is the $2^{\text {nd }}$ largest cultivated mushroom in the world and its annual production is 797,000 tones. India produces only small quantity (25000 tons) of oyster mushroom in the state of Orissa, Karnataka, Maharashtra and Andhra Pradesh etc..

Various Pleurotus species have been shown to possess a number of medicinal properties, such as antitumor, immunemodulatory, antigenotoxic, antioxidant, anti-inflammatory, hypochloesterolaemic, antihypertensive, antiviral and antimicrobial activity (Gregori et al, 2007) ${ }^{[5]}$. The production of oyster mushroom has been increasing steadily recent past years. with the availability of sub tropical climate in most part of India, widely adoptability, low coat growing technology, high biological efficiency, ability to grow on variety of agro- wastes and easy to adopt cultivation technology, the cultivation of oyster mushroom has been popularized in various state of country.

There are quite suitable for commercial cultivation of various Pleurotus species including $P$. sajar-caju, P. eous, $P$. florida, P. flabellatus, $P$. ostreatus etc. Pleurotus eous produces pinkish coloured fruit bodies either singly or in clusters. The pileus is oyster shaped initially but becomes deeply lobed and folded at maturity. The stipe is solid, rigid, eccentric and pink in
Corresponding Author: Jaydip B Anarse P.G. Student, Department of Plant Pathology, Vasantrao Naik Marathwada Krishi Vidyapeeth, Parbhani, Maharashtra, India 
colour. This mushroom grew excellently at $18-24{ }^{\circ} \mathrm{C}$ temperature range but can grow up to $28{ }^{\circ} \mathrm{C}$.

\section{Materials and Methods \\ Effect of different culture media}

To study the effect of different liquifiable solid cultural media on cultural characterstics of $P$. eous, eight culture media viz., Ashby's manitol agar, yeast extract agar, yeast manitol agar, Corn meal agar, Potato dextrose agar, potato malt agar, Czapek's dox agar and Malt extract agar were used. The media were steralized in autoclave at $15 \mathrm{LBS} /$ inch $^{2}$ pressure for $20 \mathrm{~min}$. Autoclaved and cooled media were poured @ $20 \mathrm{ml} /$ plate in steralized glass Petri plates $(90 \mathrm{~mm} \mathrm{dia}$.), and allowed to solidify at room temperature. On solidification of the media, Petriplates of each culture medium (two plates/medium/replication) were inoculated by placing at the centre $5 \mathrm{~mm}$ mycelia disc of actively growing seven days old pure cultures of $P$. eous and incubated at $20^{\circ} \mathrm{C}$ temperature.

\section{Experimental details}

Design : Completely Randomized Design (CRD)

Replications : Three

Treatments : Eight

\section{Treatment details}

$\mathrm{T}_{1}$ : Ashby's manitol agar $\mathrm{T}_{5}$ : Malt extract agar

$\mathrm{T}_{2}$ : Yeast extract agar $\quad \mathrm{T}_{6}$ : Potato malt agar

$\mathrm{T}_{3}$ : Czapek's dox agar $\quad \mathrm{T}_{7}$ : Corn meal agar
$\mathrm{T}_{4}$ : Yeast manitol agar $\quad \mathrm{T}_{8}$ : Potato dextrose agar (PDA)

The observations on radial mycelia growth/colony diameter $(\mathrm{mm})$ were recorded at 24 hours interval and continued till 10 days after inoculation. Observations obtained were averaged and the data was analyzed statistically.

\section{Statistical analysis}

All the data related to diseases incidence and yield was statistically analyzed. Calculations were made after applying the test of significance of the means (Panse and Sukhatme, 1978) ${ }^{[7]}$.

\section{Result and discussion \\ Effect of different culture media}

The effect of eight different culture media on colony diameter, color and growth type of $P$. eous were studied and observation obtained were presented in the table 1 and depicted in the PLATE II and Fig. 1.

The average colony diameter of $P$. eous in present investigation ranged between 14.66 to $90 \mathrm{~mm}$. The maximum colony diameter of $P$. eous was recorded on potato dextrose agar $(90 \mathrm{~mm})$, followed by Malt extract agar (88.16), Yeast manitol agar $(87.50 \mathrm{~mm})$, Yeast extract agar $(86.33 \mathrm{~mm})$,Corn meal agar (86.10), Potato malt extract (85.66) and minimum colony diameter was recorded on Ashby's manitol agar (14.66 $\mathrm{mm})$ which was lesser than Czapek's dox agar $(85.30 \mathrm{~mm})$.

Table 1: Effect of various culture media on growth of $P$. eous

\begin{tabular}{|c|c|c|c|c|}
\hline Tr. No. & Treatments & Avarage colony Diameter (mm) & Color of colony & Type of growth of colony \\
\hline $\mathrm{T}_{1}$ & Ashby's manitol agar & 14.66 & Light pink & Flatted \\
\hline $\mathrm{T}_{2}$ & Malt extract agar & 88.16 & Whitish & Rised puffed \\
\hline $\mathrm{T}_{3}$ & Yeast extract agar & 86.33 & Pink & Rised puffed \\
\hline $\mathrm{T}_{4}$ & Potato malt agar & 85.66 & Whitish & Rised puffed \\
\hline $\mathrm{T}_{5}$ & Czapek's dox agar & 85.30 & Light pink & Flatted \\
\hline $\mathrm{T}_{6}$ & Corn meal agar & 86.10 & Pink & Flatted \\
\hline $\mathrm{T}_{7}$ & Yeast manitol agar & 87.50 & Whitish Pink & Rised puffed \\
\hline $\mathrm{T}_{8}$ & Potato dextrose agar & 90.00 & Pink & Flatted \\
\hline \multicolumn{2}{|c|}{ S.E. \pm} & 0.74 & & \\
\hline & C.D. $1 \%$ & 2.23 & & \\
\hline \multicolumn{2}{r}{ C.V. } & 1.19 & & \\
\hline
\end{tabular}

*: Mean of three replication.

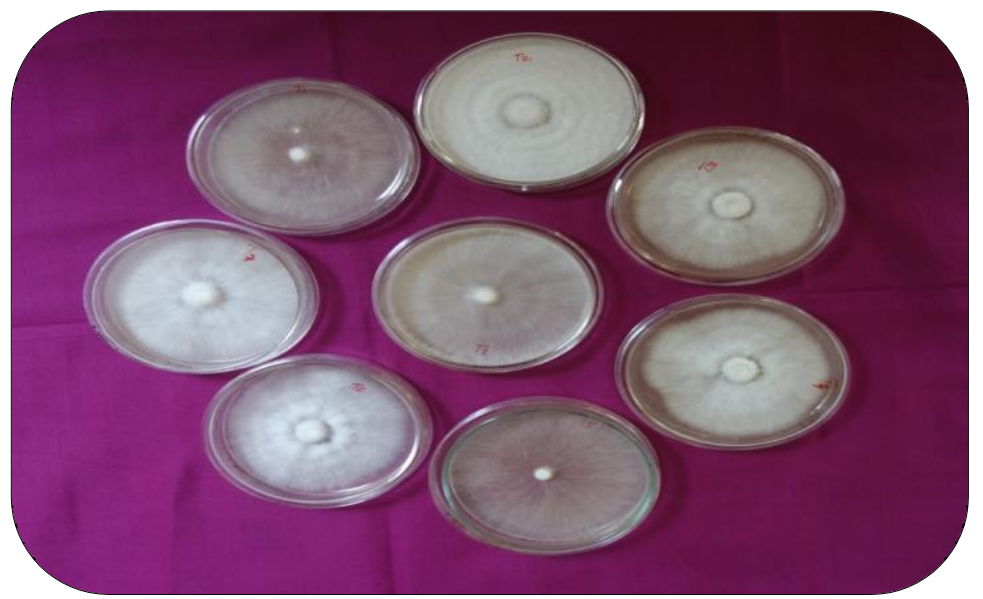

$\mathrm{T}_{1}$ : Ashby's manitol agar $\mathrm{T}_{5}$ : Czapek's dox agar

$\mathrm{T}_{2}$ : Malt extract agar $\quad \mathrm{T}_{6}$ : Corn meal agar

$\mathrm{T}_{3}$ : Yeast extract agar $\quad \mathrm{T}_{7}$ : Yeast manitol agar

$\mathrm{T}_{4}$ : Potato malt agar $\quad \mathrm{T}_{8}$ : Potato dextrose agar

Plates I: Effect of various culture media on growth of $P$. eous 
The colour and growth of $P$. eous on potato dextrose agar was recorded pink and flattened growth followed by Ashby's manitol agar (light pink and flattened growth), Yeast manitol agar (whitish pink and puffed growth) and brownish white and flattened growth on Czapek's dox agar, creamy white and raised puffed growth on Yeast extract agar.

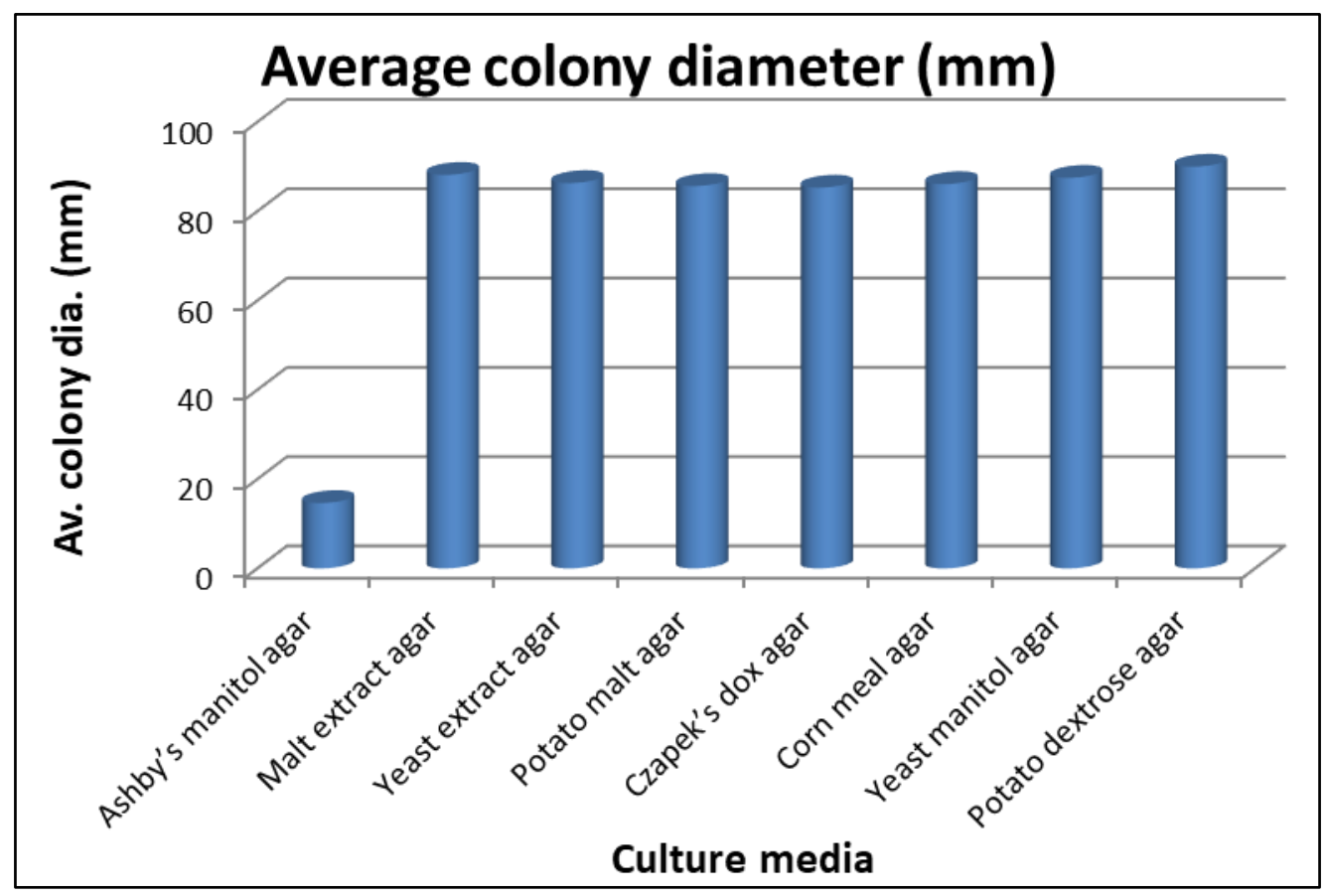

Fig 1: Effect of different culture media on growth of $P$. eous

Potato dextrose agar reported superior over all culture medium in present investigation. Similar variation in colony diameter of culture of $P$. eous has been reported by earlier workers (Gibriel et al., 1996; Dey et al., 2007; Bhatt et al., 2010; Thulasi et al., 2010; Rawate and Diwan., 2011; Stanley and Nyenke., 2011; Mansue et al., 2012 and Uddin et al.,

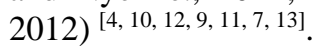

\section{Conclusion}

The maximum colony diameter of $P$. eous was recorded on potato dextrose agar $(90 \mathrm{~mm})$, followed by Malt extract agar (88.16), Yeast manitol agar $(87.50 \mathrm{~mm})$, Yeast extract agar (86.33 mm),Corn meal agar (86.10), Potato malt extract (85.66) and minimum colony diameter was recorded on Ashby's manitol agar $(14.66 \mathrm{~mm})$ which was lesser than Czapek's dox agar $(85.30 \mathrm{~mm})$.

\section{References}

1. Bhatt P, Singh RP, Sati SC. Evaluation of different Pleurotus hybrid for their growth requirment in-vitro. Indian phytopath. 2010; 63(40):424-426.

2. Chadha KL, Sharma. Advances in Horticulture 1995; 13:109-116.

3. Dey RC, Nasiruddin KM, Mamsur A. Effect of different harmone, media and varity on mycelial growth of mushroom. J Bangladesh Agril. Univ. 2017; 5(2):181187.

4. Gibriel AY, Ahmed M, Rasmy N, Rizk I, Abdel-Rehem NS. Cultivation of oyster mushroom (Pleurotus spp.): Evaluation of different media and organic substrates. Mush. Biol. Mush. Prod. 1996; 1(3):415-421.

5. Gregari A, Svageli M, Pohleven J. Cultivation techniques and medicinal properties of Pleurotus Spp. Food Technol. Biotechnol. 2007; 45(3):236-247.

6. Mansur MAZ, Miah A, Rahaman MH, Rahman MM, Yahia ASM. Effect of various media on mycelia growth and substrate on spawn production of oyster mushroom. Bangladesh Res. Public. J. 2012; 7(4):361-366.

7. Panse VG, Sukhatme PV. Statistical Methods for Agricultural Workers. ICAR Publication, New Delhi 1967, 383.

8. Prakasam V. Current scenario of Mushroom Research in India 2012; 65(1):1-11.

9. Rawte H, Diwan R. Growth response of Pleurotus spp. on different basal media and different $\mathrm{pH}$ levels. J Ecobiotechno. 2011; 3(4):10-12.

10. Singh MB, Vijay S, Kamal, Wakcaure. Mushroom cultivation, marketing and consumption. Directorate of Mushroom Research, Solan 2011, 266.

11. Stanley HO, Nyenke CU. Cultural studies on mycelia of Pleurotus plumonarius (oyster mushroom) in selected culture media. Int. J. Sci. Nat. 2011; 2(2):183-185.

12. Thulasi EP, Thomas PD, Ravichandran B, Madhusudhan K. International J. of Biol. Techno. 2010; 1(3):39-42.

13. Uddin MJ, Nasiruddin KM, Haque ME, Biswas AK, Islam MS. Influence of different media variety and growth regulator on mycelial colony proliferation of mushroom. J Environ. Sci. Natural resources. 2012; 5(1):223-227. 